\title{
Extensive direct measurements of Posidonia oceanica defoliation confirm the importance of herbivory in temperate seagrass meadows
}

\author{
Patricia Prado $^{1, *}$, Fiona Tomas ${ }^{1,2}$, Teresa Alcoverro' ${ }^{1}$, Javier Romero ${ }^{3}$ \\ ${ }^{1}$ Centro de Estudios Avanzados de Blanes, c/ Accés a la Cala St. Francesc 14, 17300 Blanes, Girona, Spain \\ ${ }^{2}$ Scripps Institution of Oceanography, University of California San Diego, 9500 Gilman Drive, La Jolla, \\ California 92093-0202, USA \\ ${ }^{3}$ Departamento de Ecología, Facultad de Biología, Universidad de Barcelona, Avda. Diagonal 645, 08028 Barcelona, Spain
}

\begin{abstract}
The rates of seagrass defoliation exerted by the herbivorous fish Sarpa salpa and by the sea urchin Paracentrotus lividus were evaluated through both direct (tethering experiment) and indirect (bite marks) methods. Sampling was conducted once per season in 10 shallow meadows of Posidonia oceanica (L.) Delile from the continental NW Mediterranean coast covering a spatial scale of $>300 \mathrm{~km}$. Results indicated that a large proportion (ca. $57 \%$ ) of the annual leaf production is lost to herbivory, yet with considerable spatial variation. Patterns of seagrass defoliation showed high temporal variability, with a peak in summer with values that exceeded about 2.5 times those of leaf production and a minimum during the winter period. On average, defoliation exerted by $S$. salpa accounted for $40 \%$ of leaf production (ca. $70 \%$ of total annual losses to herbivory), while P. lividus was also responsible for a substantial $17 \%$ removal of leaf production. High discrepancies encountered when comparing direct and indirect measurements suggest that the latter are inappropriate to achieve accurate estimates of herbivory pressure. This study evidences that $P$. oceanica leaf losses to herbivores are not marginal, but a widespread process that occurs at much higher rates than previously estimated through indirect methods (ca. $2 \%$ ), resetting the paradigm of the negligible importance of herbivory in temperate systems.
\end{abstract}

KEY WORDS: Tethering experiment · Temporal variation · Posidonia oceanica $\cdot$ Seagrass defoliation • Sarpa salpa $\cdot$ Paracentrotus lividus $\cdot$ Bite marks

Resale or republication not permitted without written consent of the publisher

\section{INTRODUCTION}

Herbivory is considered to be one of the major forces shaping plant communities (Cyr \& Pace 1993), playing a major role not only in trophic organization, but also in the control of plant abundance, distribution, and evolution. Yet, direct consumption of seagrass has often been considered to play a minor role. This is based on the generally low grazing rates reported, which represent, despite considerable inter-specific variation, about $10 \%$ annual net aboveground primary production (review by Cebrián \& Duarte 1998). Such low rates have been related to high $\mathrm{C}: \mathrm{N}$ ratios in seagrass leaves, which have a lesser nutritional value than algae (Duarte 1990), as well as to the presence of cellulose, which cannot be easily digested by many marine organisms, and may act as a structural deterrent (Bjorndal 1980). Although sea turtles, sirenians and waterfowls are recognized as important seagrass consumers (Preen 1995, Ganter 2000, Moran \& Bjorndal 2005), in their absence, herbivory has usually been considered a marginal process in seagrass ecosystems. Nevertheless, there is increasing worldwide evidence that pressure exerted by marine herbivores other than these large vertebrates may also play an important role in the energetics and interaction network of seagrass ecosystems (see review by Heck \& Valentine 2006). For instance, many species of sea urchins and herbivorous 


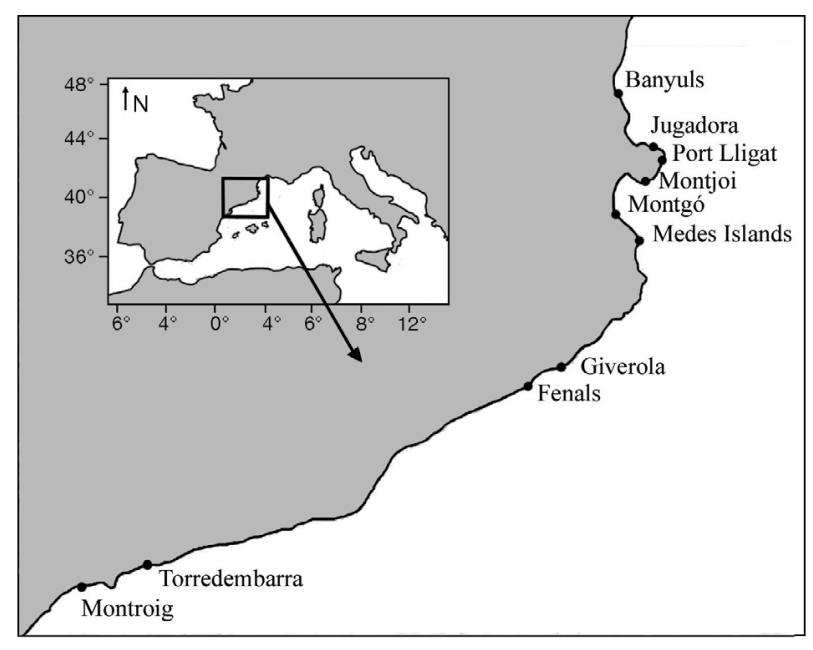

Fig. 1. Map of the NW Mediterranean showing the position of the study sites on the continental Spanish coast

fish throughout the world (Valentine \& Heck 1991, Kirsch et al. 2002, Alcoverro \& Mariani 2004, Tomas et al. 2005) feed regularly on seagrasses and can determine, at least in part, their distribution, abundance, or the structure of their associated communities. However, to date, only few studies have used direct methods to estimate total rates of seagrass defoliation by herbivores and to assess variability on a large scale (but see Kirsch et al. 2002, Tomas et al. 2005). These types of studies are necessary to clarify the role of grazing in seagrass ecosystems.

In particular, herbivory losses on the endemic Mediterranean species Posidonia oceanica (L.) Delile are amongst the lowest reported for seagrasses, with values around $2 \%$ of leaf production (Cebrián et al. 1996). These estimates, although obtained from largescale data $(900 \mathrm{~km})$, were based on indirect measures of herbivore bite marks. Such low values would seem to be in conflict with the relatively high abundance of the 2 main seagrass herbivores, the sea urchin Paracentrotus lividus (Lam.) (Boudouresque \& Verlaque 2001) and the fish Sarpa salpa (L.), whose schools are common in shallow Mediterranean waters (seagrass meadows and rocky bottoms; Verlaque 1990). Indeed, a recent study using direct measurements of seagrass losses has provided evidence that herbivory by $S$. salpa in undisturbed $P$. oceanica meadows can be substantial, with defoliation reducing up to $50 \%$ of plant biomass (Tomas et al. 2005). Moreover, overgrazing by $P$. lividus and $S$. salpa has been observed on several occasions (e.g. Nedelec \& Verlaque 1984, Ruiz et al. 2001, Tomas et al. 2005). All these facts highlight the need for a broader re-assessment of the importance of herbivory in Mediterranean meadows.
Hence, the objective of the present study was to reexamine the importance of herbivory in the temperate Posidonia oceanica ecosystem by quantification of the defoliation rates exerted by the 2 main $P$. oceanica consumers, the fish Sarpa salpa and the sea urchin Paracentrotus lividus. To do this, direct methods to estimate seagrass defoliation were carried out across a spatial scale as large as possible (ca. $300 \mathrm{~km}$ ), taking into account the important temporal variability in fish activity (Tomas et al. 2005).

\section{MATERIALS AND METHODS}

Study site and sampling design. Leaf production (Romero 1989) and herbivore pressure (Tomas et al. 2005) are highest in shallow waters. The fish Sarpa salpa is commonly seen feeding at depths between 3 and $10 \mathrm{~m}$ (but up to $20 \mathrm{~m}$ ), particularly during the warm period (i.e. late June to late September; Tomas et al. 2005), and densities of the sea urchin Paracentrotus lividus are higher in the upper sublittoral (0.5 to $10 \mathrm{~m}$; Boudouresque \& Verlaque 2001). Therefore, the present study was undertaken within the depth range of maximum herbivore density (i.e. 5 to $8 \mathrm{~m}$ depth), where herbivores can potentially have a relevant effect on the local communities of Posidonia oceanica. Seagrass defoliation by herbivores was examined in 10 shallow $P$. oceanica beds on the northeast Spanish coast and in the south of France (NW Mediterranean), embracing a total extension of ca. $300 \mathrm{~km}$. Selected sites were Montroig, Torredembarra, Fenals, Giverola, Medes Islands, Montgó, Montjoi, Port Lligat, Jugadora, and Banyuls (see Fig. 1).

Sampling was performed at 4 different times of the year, to encompass the seasonal variation in densities and/or activity of herbivores, especially of Sarpa salpa. Large schools of this species start appearing in midspring, as they leave wintering and spawning areas at greater depths (Verlaque 1990). Fish densities in shallow seagrass beds are highest during the summer, decrease during the fall, and reach annual minimums from late autumn to early spring (Francour 1997, Tomas et al. 2005). Sampling was accordingly conducted in June 2004 (appearance period), August 2004 (period of maximum fish abundance), November 2004 (departure period), and March 2005 (period of minimum abundance).

Measurements of seagrass defoliation and productivity. A tethering experiment (Kirsch et al. 2002) was conducted to obtain direct quantification of Posidonia oceanica defoliation by macroherbivores. At each site, we collected $30 \mathrm{P}$. oceanica shoots haphazardly at 5 to $8 \mathrm{~m}$ depth, depending on the site. Care was taken to select shoots that had sufficient vertical rhizome to 
allow the safeguarding of leaves (typically 4 to 7 ) throughout the experiment. After collection, the tips of the leaves were cut to remove scars left by previous herbivore attacks, and the number of leaves and their length (to the nearest $\mathrm{mm}$ ) were recorded. Shoots presenting leaves with lateral bites were discarded. The base of the leaves was also marked using a modified Zieman method (Romero 1989) in order to detect possible leaf elongation of uprooted shoots during the experiment. In order to optimize retrieval of samples, individual shoots were attached by their vertical rhizome to a labeled line of pickets, each line carrying a total of 5 labeled pickets. Shoots within a line were separated from each other by approximately $1.5 \mathrm{~m}$. Four lines were set up inside the meadow at each site at the same depth of collection, lines being placed approximately one after the other, and, thus, each picket was considered an independent sample. When inserting pickets into the sediment, maximum care was taken to ensure that leaves were neither above nor below the average height of the leaf canopy. During the manipulation period, shoots were kept underwater to avoid potential stress and loss of epiphytes, thus minimizing potential tethering artifacts.

Tethered shoots were left at each study site during $2 \mathrm{wk}$, as it has been shown that no significant changes in leaf quality occur during that period of time (Tomas et al. 2005), and then retrieved for further sorting. Once in the laboratory, leaf length and width, the number of leaves per shoot that were lost, broken (wave action), intact, or attacked by grazers, and the numbers of bite marks per leaf were recorded. Both herbivores leave bite marks of identifiable shape (Boudouresque \& Meisnez 1982). On the one hand, the sea urchin grinds seagrass leaves using Aristotle's lantern, which results in irregularly slashed scars. On the other, the morphology of the fish jaw apparatus produces neat, semicircular bites (see Fig. 2a,b). Therefore, accurate estimates of leaf area removed by each of these bites can be obtained by scanning the leaves.

Leaf elongation rate $\left(\mathrm{cm}^{2}\right.$ shoot $\left.^{-1} \mathrm{~d}^{-1}\right)$ of tethered shoots (the purpose of such assessment being only to correct defoliation estimates) was determined by dividing the area of new tissue produced by the number of days elapsed since marking (i.e. 15 d). These data were available for the sampling events in August, November, and March, whereas those of June were estimated as the average between August and March values. This extrapolation might represent a source of error, but elongation rates of uprooted shoots were low compared to attached shoots.

Seagrass defoliation was estimated by subtracting the leaf area remaining from each initial shoot measurement and by adding the growth area of the tethered shoots obtained after $2 \mathrm{wk}$, and were expressed in

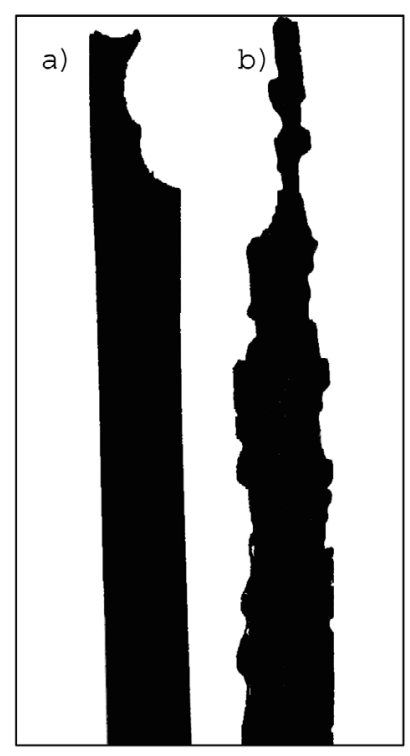

Fig. 2. Posidonia oceanica. Image of leaves displaying morphologically distinctive bite marks of: (a) Sarpa salpa and (b) Paracentrotus lividus

$\mathrm{cm}^{2}$ shoot $^{-1} \mathrm{~d}^{-1}$ (Kirsch et al. 2002). Leaves that were lost during this period were not included in the analyses, which may cause an underestimation of the total defoliation rates. The number of bite marks per shoot (the indirect method that has generally been used to estimate seagrass herbivory) and the leaf tissue consumed by each herbivore provided the means to test the accuracy of indirect versus direct methods of calculating herbivore pressure.

Monthly values of leaf productivity at the depth of the study (i.e. 5 to $8 \mathrm{~m}$ ) were compiled from the available literature from different years and from locations in the northwestern Mediterranean. Rates of leaf production for each month of the year were expressed in terms of $\mathrm{cm}^{2}$ shoot $^{-1} \mathrm{~d}^{-1}$ (i.e. leaf elongation) and then compared to seagrass defoliation obtained during the 4 different sampling times. To estimate annual defoliation rates, we assigned the obtained values to appropriate intervals as follows: January to May, March rates; June to July, June rates; August to September, August rates; October to November, November rates; and December to May, March rates. These intervals were assigned based on available knowledge of the seasonal feeding behavior of Sarpa salpa (Verlaque 1990, Tomas et al. 2005), and can be considered conservative, as we used a 6 mo period (i.e. December to May) as the period of low feeding activity, which is an upper estimate. Moreover, our data have good temporal resolution during the period of maximum consumption.

Statistical analyses. Variability in the defoliation rates by Sarpa salpa and Paracentrotus lividus and in 


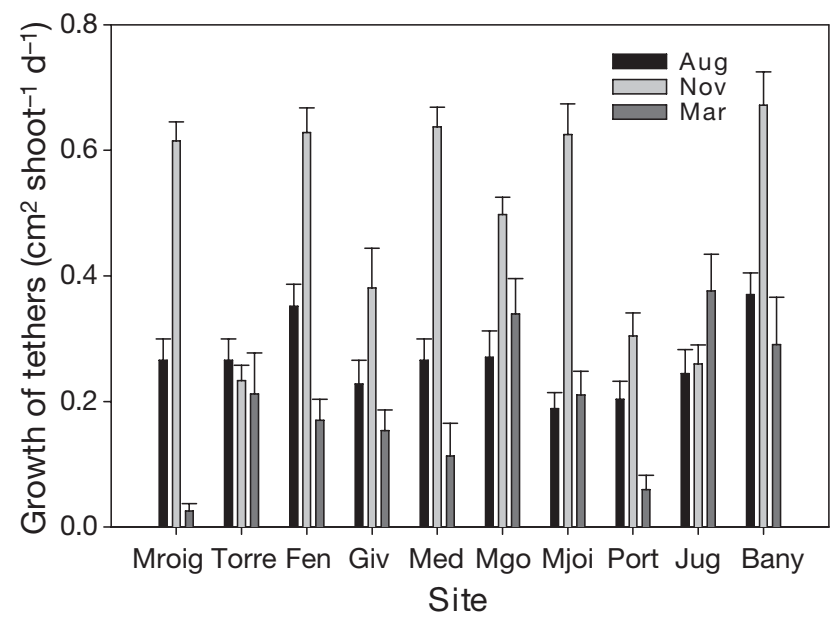

Fig. 3. Posidonia oceanica. Temporal differences in the growth of tethers at each study site. Errors bars: +SE. Mroig: Montroig, Torre: Torredembarra, Fen: Fenals, Giv: Giverola, Med: Medes Islands, Mgo: Montgó, Mjoi: Montjoi, Port: Port Lligat, Jug: Jugadora, Bany: Banyuls

the number of bite marks per shoot were assessed using a 2-way ANOVA (time fixed; site random). ANOVA assumptions of normality (Chi-squared test) and heteroscedasticity (Cochran's test) of data were not always achieved by transformation. The ANOVA $F$-statistic is, however, still able to provide robust results provided that the working sample size is large enough and the risk of making a Type I error was minimized by setting the level of significance to 0.01 (Underwood 1997). Significant differences among sampling times and sites were further investigated by Student-Newman-Keuls (SNK) post hoc comparisons.

The existence of an association between the number of bites by each herbivore (i.e. Sarpa salpa and Paracentrotus lividus) and their defoliation rate per shoot was assessed by regression analysis. To this end, shoots from each sampling site and period were pooled, and average values (i.e. 10 sites $\times 4$ sampling times) were regressed to observed measures of defoliation.

\section{RESULTS}

\section{Growth of tethered shoots}

Elongation of uprooted tethered shoots was detected at all sampling times, with the highest $( \pm \mathrm{SE})$ value in November $\left(0.48 \pm 0.055 \mathrm{~cm}^{2}\right.$ shoot $\left.^{-1} \mathrm{~d}^{-1}\right)$, the minimum in March $(0.195 \pm 0.036)$, and an intermediate value in August $(0.26 \pm 0.018$; see Fig. 3$)$. These values represented about one-third of the growth of unmanipulated shoots (obtained from the literature), the seasonal pattern being different as well (Alcoverro et al. 1995).

\section{Seagrass defoliation}

Mean $( \pm \mathrm{SE})$ annual defoliation of seagrass (i.e. all sampling times and sites pooled) was estimated at ca. $0.523 \pm 0.17 \mathrm{~cm}^{2}$ shoot $^{-1} \mathrm{~d}^{-1}$, while the mean leaf production obtained from monthly records available in the compiled literature (see Fig. 4) was ca. $0.91 \pm 0.25 \mathrm{~cm}^{2}$ shoot $^{-1} \mathrm{~d}^{-1}$. Therefore, seagrass defoliation was grossly estimated as ca. $57 \%$ of leaf production, and Sarpa salpa was confirmed to be the main herbivore $\left(t_{39}=\right.$ $3.68 ; \mathrm{p}<0.001$ ). On an annual basis (i.e. the mean value resulting from pooling defoliation rates obtained from estimates of the 4 sampling times; see 'Materials and methods'), fish accounted for a daily mean value of seagrass defoliation of ca. $0.365 \pm 0.08 \mathrm{~cm}^{2}$ shoot $^{-1} \mathrm{~d}^{-1}$ (ca. $70 \%$ of total annual defoliation), whereas the sea urchin Paracentrotus lividus accounted for a lower rate (ca. $0.158 \pm 0.04 \mathrm{~cm}^{2}$ shoot $^{-1} \mathrm{~d}^{-1}$; ca. $30 \%$ of total annual defoliation).

Total seagrass defoliation during the study (i.e. Sarpa salpa and Paracentrotus lividus) showed both important spatial differences and significant temporal variability (Table 1, Fig. 5a-d). Differences among sites were generally high throughout the year; however, variability was higher during sampling events in late spring and in the fall and was lowest in summer (Coefficient of variation: $\mathrm{CV}_{\text {jun }}=96 \%, \mathrm{CV}_{\text {aug }}=36 \%$, $\mathrm{CV}_{\text {nov }}=80 \%, \mathrm{CV}_{\text {mar }}=72 \%$ ). In general terms, herbivore defoliation was clearly higher than leaf produc-

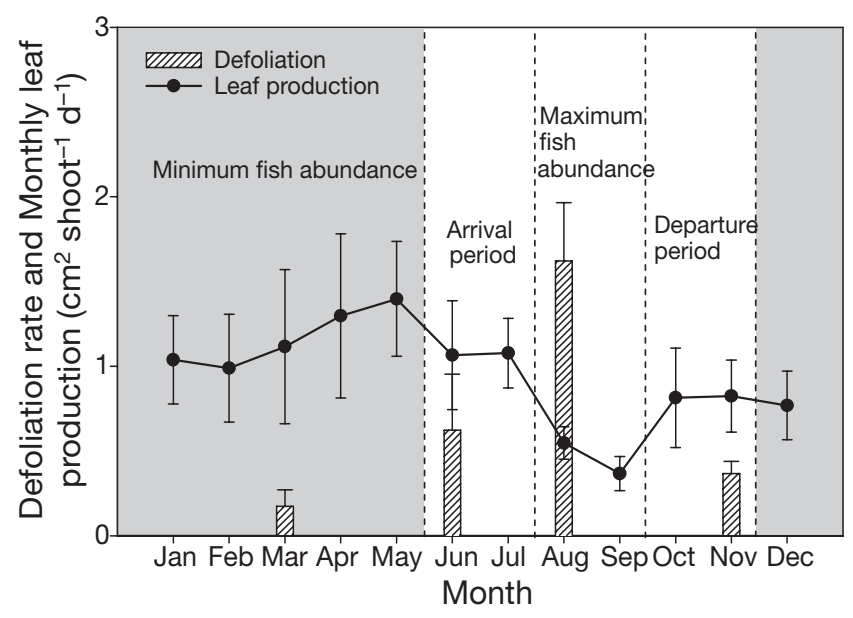

Fig. 4. Posidonia oceanica. Vertical bars indicate differences in the total rates of defoliation (i.e. by Sarpa salpa and Paracentrotus lividus) at each sampling time (all sites pooled). Line graph shows the monthly trends of leaf production $\left(\mathrm{cm}^{2}\right.$ shoot $^{-1} \mathrm{~d}^{-1}$ ) compiled from the literature (Ott 1980, Wittmann 1984, Romero 1989, Esteban et al. 1990, Alcoverro et al. 1995). Dotted lines indicate the seasonal periods of fish abundance for which measured rates of defoliation have been compared to estimate the total annual loss to herbivory (i.e. $57 \%$ of annual leaf production). Error bars: $\pm \mathrm{SE}$ 
Table 1. Posidonia oceanica. ANOVA results on seagrass losses to herbivores at the 4 different sampling times: total defoliation, defoliation by the fish Sarpa salpa, and defoliation by the sea urchin Paracentrotus lividus. Significant results are given in bold. $C$ : Cochran's C-statistic. SNK: Student-Newman-Keuls test. B: Banyuls; J: Jugadora; P: Port Lligat; Mj: Montjoi; Mg: Montgó; M: Medes Islands; G: Giverola; F: Fenals; T: Torredembarra; Mr: Montroig

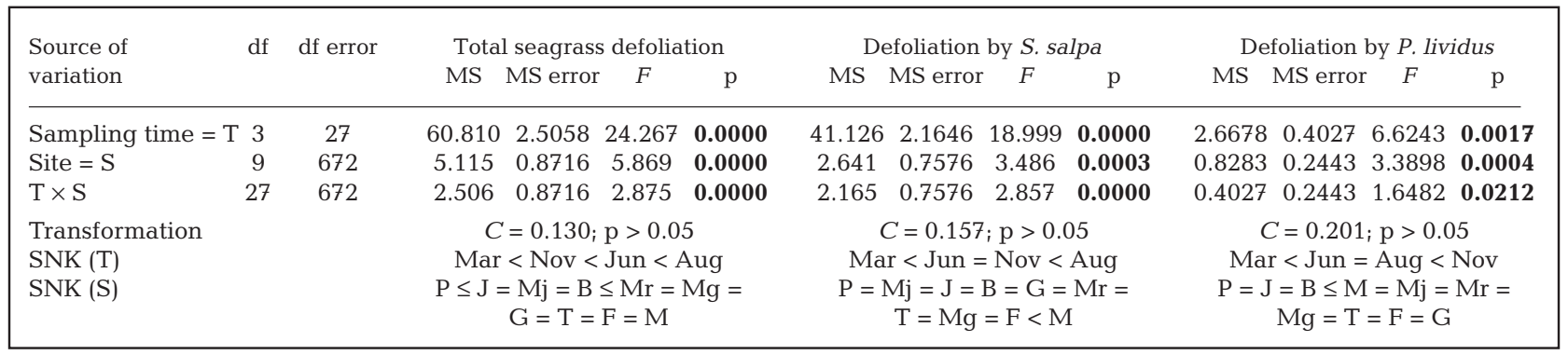
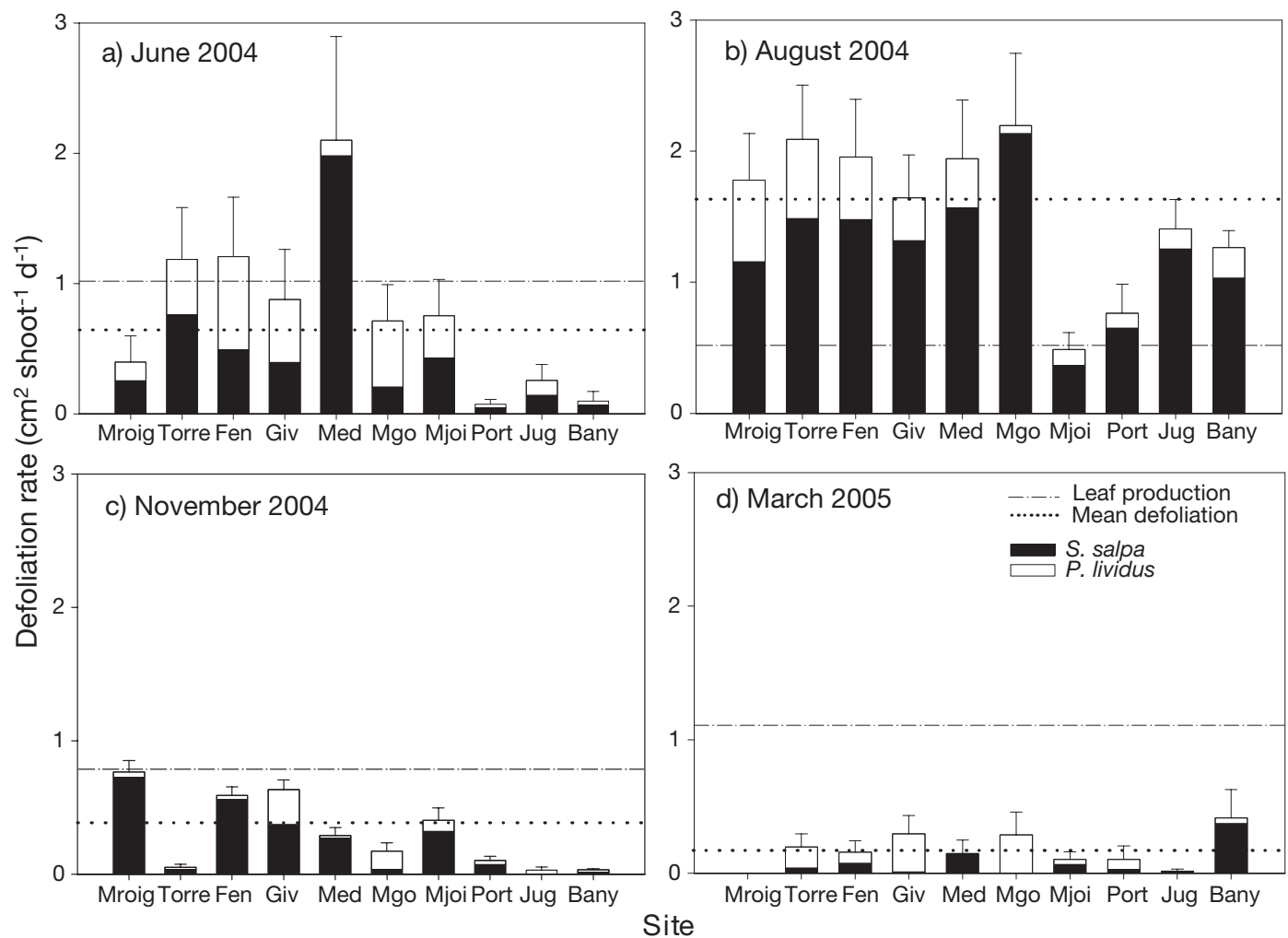

Fig. 5. Posidonia oceanica. Temporal differences in defoliation rates by Sarpa salpa and Paracentrotus lividus at each study site (see Fig. 1). (---) Average values of leaf production from the literature $\left(\mathrm{cm}^{2}\right.$ shoot $\left.^{-1} \mathrm{~d}^{-1}\right)$ (see references in Fig. 4) (....) Mean seagrass losses to herbivores at each study site. Mroig: Montroig, Torre: Torredembarra, Fen: Fenals, Giv: Giverola, Med: Medes Islands, Mgo: Montgó, Mjoi: Montjoi, Port: Port Lligat, Jug: Jugadora, Bany: Banyuls. Error bars $=+\mathrm{SE}$

tion in summer and lower in autumn and winter, while in early summer (i.e. June) it showed important variations subjected to the arrival of $S$. salpa to each site. Hence, defoliation by fish showed remarkable spatial and temporal variation, depending on the total period of time that fish remained in the shallow meadow (significant Site $\times$ Time interaction), though, in general terms, defoliation increased from the sampling time in spring $\left(0.47 \pm 0.18 \mathrm{~cm}^{2}\right.$ shoot $\left.^{-1} \mathrm{~d}^{-1}\right)$ to mid-summer
(1.24 $\pm 0.15 \mathrm{~cm}^{2}$ shoot $\left.^{-1} \mathrm{~d}^{-1}\right)$ and decreased in fall $\left(0.24 \pm 0.08 \mathrm{~cm}^{2}\right.$ shoot $\left.^{-1} \mathrm{~d}^{-1}\right)$ and winter (March; $0.075 \pm$ $0.03 \mathrm{~cm}^{2}$ shoot ${ }^{-1} \mathrm{~d}^{-1}$ ) (Table 1, Fig. 5a-d). Similarly, spatial differences in rates of seagrass defoliation by $P$. lividus were connected to the time of the sampling event (significant Site $\times$ Time interaction). Recorded values for this species were generally lower than those of $S$. salpa, except for the winter sampling, when fish densities were at their lowest values. On the other 
Table 2. Posidonia oceanica. ANOVA results on number of Sarpa salpa and Paracentrotus lividus bite marks after each collection of tethered shoots. Significant results are given in bold. For abbreviations, see Table 1

\begin{tabular}{|c|c|c|c|c|c|c|c|c|c|c|}
\hline \multirow{2}{*}{$\begin{array}{l}\text { Source of } \\
\text { variation }\end{array}$} & \multirow[t]{2}{*}{ df } & \multirow[t]{2}{*}{ df error } & \multicolumn{4}{|c|}{ S. salpa bite marks } & \multicolumn{4}{|c|}{ P. lividus bite marks } \\
\hline & & & MS & MS error & $F$ & $\mathrm{p}$ & MS & MS error & $F$ & $\mathrm{p}$ \\
\hline Sampling time $=\mathrm{T}$ & 3 & 670 & 890.28 & 212.61 & 4.187 & 0.0148 & 2.3578 & 2.6172 & 0.9005 & 0.4537 \\
\hline Site $=\mathrm{S}$ & 9 & 670 & 135.71 & 13.686 & 9.916 & 0.0000 & 4.3594 & 0.9009 & 4.8390 & 0.0000 \\
\hline $\mathrm{T} \times \mathrm{S}$ & 27 & 670 & 212.61 & 13.686 & 15.534 & 0.0000 & 2.6182 & 0.9009 & 2.9062 & 0.0000 \\
\hline \multirow{3}{*}{\multicolumn{3}{|c|}{$\begin{array}{l}\text { Transformation } \\
\text { SNK (T) } \\
\text { SNK (S) }\end{array}$}} & \multicolumn{4}{|c|}{$C=0.264 ; \mathrm{p}>0.05$} & \multicolumn{4}{|c|}{$C=0.09 ; \mathrm{p}>0.05$} \\
\hline & & & \multicolumn{4}{|c|}{ Mar $=$ Jun $<$ Nov $=$ Aug } & \multirow{2}{*}{\multicolumn{4}{|c|}{$\begin{array}{c}\mathrm{J}=\mathrm{P}=\mathrm{M} \leq \mathrm{Mr}=\mathrm{Mj}=\mathrm{B}= \\
\mathrm{F}=\mathrm{T}=\mathrm{G}=\mathrm{Mg}\end{array}$}} \\
\hline & & & & $\begin{array}{r}\quad J=B=M \\
G \leq F=N\end{array}$ & $\begin{array}{l}\mathrm{ij}=\mathrm{T} \leq \\
\mathrm{Mg}=\mathrm{Mr}\end{array}$ & & & & & \\
\hline
\end{tabular}
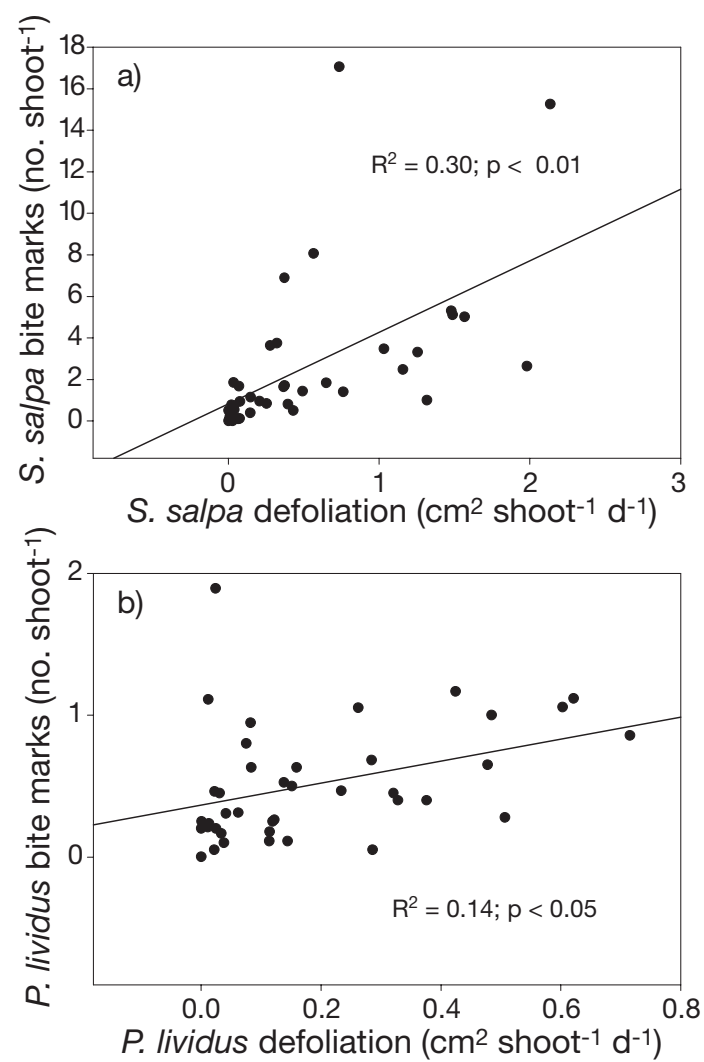

Fig. 6. Posidonia oceanica. Relationship between the numbers of bite marks (i.e. indirect method) and the mean defoliation rates (i.e. direct method) by: (a) Sarpa salpa and (b) Paracentrotus lividus for each study site (all sampling times included)

hand, the influence of sampling time was also made evident by generally higher defoliation rates in spring to summer $\left(0.29 \pm 0.07 \mathrm{~cm}^{2}\right.$ shoot $\left.^{-1} \mathrm{~d}^{-1}\right)$ and minimums in fall to winter $\left(0.08 \pm 0.03 \mathrm{~cm}^{2}\right.$ shoot $\left.^{-1} \mathrm{~d}^{-1}\right)$ (Table 1, Fig. 5a-d).

Only a low percentage of the leaf losses recorded during the different sampling times $(2 \pm 1.2 \%$ in June, $2 \pm 0.9 \%$ in August, $4.7 \pm 4.4 \%$ in November, and $3.9 \pm$ $1.8 \%$ in March) were attributed to mechanical breakage (wave action or other causes).

\section{Direct versus indirect methods}

The frequency of Sarpa salpa bite marks also exhibited strong temporal and spatial variation, but post hoc comparisons indicated only 2 different groups with maximum values in August and minimum values in March (see Table 2). In contrast, spatial but no temporal differences were detected in sea urchin marks (Table 2), despite observed differences in direct rates of seagrass defoliation (Table 1). When mean values for each site and sampling time were regressed together ( $\mathrm{n}=40$ ), only a weak association was found between defoliation rates and bite marks $\left(\mathrm{R}^{2}=0.30, \mathrm{p}<\right.$ 0.01 and $\mathrm{R}^{2}=0.14, \mathrm{p}<0.05$, for both $S$. salpa and Paracentrotus lividus, respectively; Fig. 6).

\section{DISCUSSION}

The results exposed here evidence the existence of a substantial defoliation of Posidonia oceanica in the examined meadows, reaching a gross annual estimate of ca. $57 \%$ of the annual leaf production. This is in contrast with previous reports obtained over a comparable depth range and geographic area (2\%; Cebrián et al. 1996) using indirect estimates based on bite marks. In summer, since Sarpa salpa feeds in large schools (Verlaque 1990) and aggregations ranging from 2 to 3 individuals of Paracentrotus lividus are not rare (Boudouresque \& Verlaque 2001), repeated attacks to the same leaf may mask the marks of previous attacks, causing underestimation of defoliation rates (see Tomas et al. 2005). Overall, herbivores are shown to play a much more important role in $P$. oceanica shallow meadows than previously thought, which is in accordance with recent views on seagrass ecosystems, whether tropical, subtropical, or temperate (Valentine et al. 1991, Ganter 2000, Kirsch et al. 2002, Alcoverro \& Mariani 2004).

Sarpa salpa alone accounted for $70 \%$ of total annual losses to herbivores (ca. $40 \%$ of leaf production). 
Indeed, this species was consistently responsible for the majority of the removed leaf material at all study sites and during most of the year, confirming the preeminence of fish in Posidonia oceanica herbivory (Cebrián et al. 1996, Tomas et al. 2005). Defoliation by $S$. salpa clearly differed among sampling times (contribution to total seagrass leaf losses ranged from $80 \%$ in August to $<50 \%$ in March). These differences are most probably caused by the seasonal migratory and feeding behavior of this species (Verlaque 1990, Tomas et al. 2005). However, spatial differences in the timing of obtained defoliation rates can be, at least in part, attributed to spatial differences in the periods of arrival and departure of fishes in spring and fall, respectively. From June to September, variability in the activity of $S$. salpa has been associated with differences in the occupation of their home sites (either persistent or intermittent during the $24 \mathrm{~h}$ cycle) depending on the local environment (Jadot et al. 2002). For instance, spatial differences may arise from variability in local hydrodynamic conditions, since shallow, sheltered sites seem to sustain greater fish biomass than those unsheltered (Francour 1997). Nevertheless, this does not seem to be the case in this study, since most of the study sites were located in sheltered areas and those few that were not, such as Torredembarra and Fenals, displayed considerable rates of defoliation (see Fig. 5). In contrast, other sources of variability, such as fishing pressure and meadow size, will need to be further investigated.

Sea urchins accounted for the remaining $30 \%$ of total annual losses to herbivores (i.e. $17 \%$ of leaf production). Defoliation rates by sea urchins also differed among sampling times, although less markedly than for fishes. These differences can be attributed to the influence of seasonal variables on feeding activity such as temperature and the nature and abundance of trophic resources (Régis 1979, Frantzis \& Grémare 1993). It is also possible that some underestimation of sea urchin defoliation occurs in summer, compared to that of Sarpa salpa, due to the masking effect caused by very high fish activity.

The effects of such important leaf losses on the plant cannot be assessed from our data. It is clear that leaf growth and defoliation by herbivores are uncoupled. Growth exceeds defoliation most of the year, but defoliation largely exceeds growth in the summer, causing

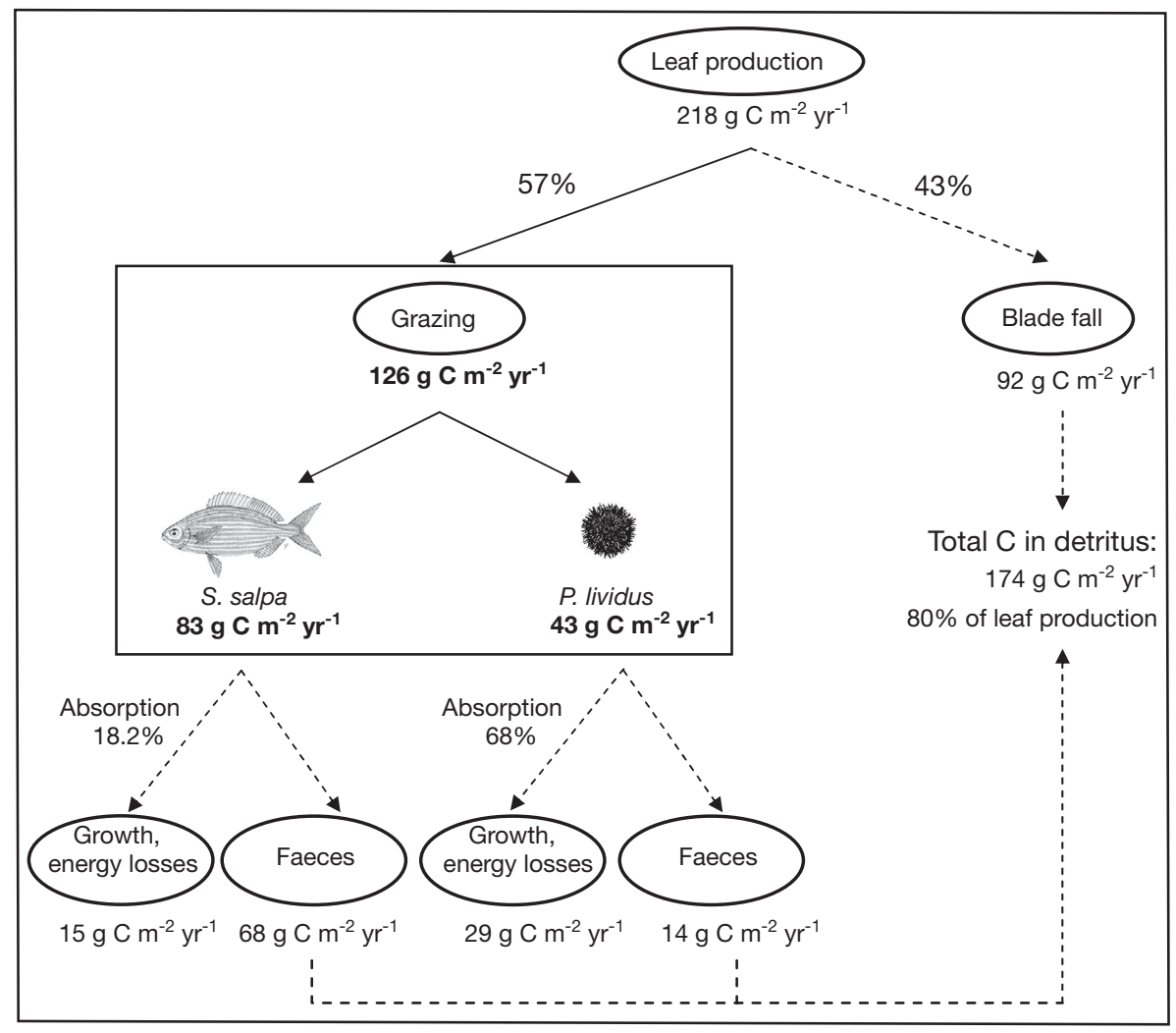

Fig. 7. Posidonia oceanica. Mean carbon fluxes in a Mediterranean meadow from the continental coast. Values from the present study are indicated in bold within the smaller square. Leaf production was calculated from the literature (see Fig. 4 for references) and then transformed to $\mathrm{g} \mathrm{C} \mathrm{m}^{-2} \mathrm{yr}^{-1}$, with shoot density values for the same region (Alcoverro et al. 1995, Marbà et al. 1996). Absorption efficiency for Sarpa salpa is from Velimirov (1984), and absorption efficiency for Paracentrotus lividus is from Frantzis 
a reduction in leaf biomass and growth (Tomas et al. 2005). In that period, leaf production is at its annual lowest (Romero 1989, Alcoverro et al. 1995), and the products of leaf photosynthesis accumulate as carbohydrate reserves in belowground organs (Alcoverro et al. 2001). It is therefore possible that the decrease in leaf area caused by intense summer grazing would reduce plant reserves for over-wintering. However, it is also possible that biomass (including epiphyte) removal would alleviate the negative effect caused by self-shading. In any case, strong grazing by Sarpa salpa in summer appears to be a relatively common phenomenon in shallow meadows that have persisted for decades (Velimirov 1984, Verlaque 1990, Tomas et al. 2005). The period of higher herbivore activity coincides with the annual lowest nutrient content in seagrass leaves (Alcoverro et al. 1995), evidencing that $\mathrm{N}$ is not the force driving the feeding behavior of S. salpa.

In light of the new results obtained on the importance of herbivory processes in shallow Posidonia oceanica meadows, our views on carbon fluxes in such ecosystems should be modified, as carbon transfer from the plant to higher levels becomes a major pathway (Fig. 7). However, in this budget model, it is necessary to note that the amount of primary production entering the secondary food web through herbivory corresponds to the maximum possible estimate, assuming that the totality of defoliated tissues are consumed by herbivores. Consumption values for Sarpa salpa may be slightly overestimated due to the fact that lateral bites exerted by large individuals may enhance leaf break by the effect of wave action; however, these cases were rare. Apparently, and due to the differential absorption efficiencies of $S$. salpa and Paracentrotus lividus (ca. 18.2 and $68 \%$, respectively; see Fig. 7 for references), the amount of seagrass $\mathrm{C}$ potentially reaching higher consumer levels through the sea urchin is higher $\left(29 \mathrm{~g} \mathrm{C} \mathrm{m}^{-2} \mathrm{yr}^{-1}\right)$ than that through fish (15 $\mathrm{g} \mathrm{C} \mathrm{m}^{-2} \mathrm{yr}^{-1}$ ). Yet, the former allocates most of the energy seen to be used to respiration, excretion, and secretion and only a small part to growth (Fernandez \& Boudouresque 2000). However, the fraction of primary production entering the litter stock, both by blade fall and by fecal remains, is still the largest component, with an estimate of ca. $80 \%$ of leaf production, confirming the importance of the detritic pathway (on average $70 \%$ of $P$. oceanica primary production; Pergent et al. 1994).

Given the bathymetric distribution of herbivores and the direct rates of seagrass leaf losses to herbivory reported in the present study, evidence is sufficient to show that shallow Posidonia oceanica meadows (i.e. 5 to $8 \mathrm{~m}$ ) function differently from those at greater depths, in terms of both control of aboveground biomass and C flux. In fact, Pergent et al. (1997) evaluated the fate of primary production at depths ranging from 10 to $20 \mathrm{~m}$ and estimated that less than 3 to $10 \%$ of the $\mathrm{C}$ was lost to herbivores. Therefore, the productivity of deep seagrass meadows is closely controlled by the light gradient (Romero 1989), whereas herbivory pressure in shallow meadows may have a greater influence than previously thought.

In conclusion, this work strongly supports that the importance of herbivory in shallow Posidonia oceanica meadows in the western Mediterranean is not simply anecdotal, and the reported cases of intense grazing (e.g. Ruiz et al. 2001, Tomas et al. 2005) could be the rule rather than the exception. Additionally, the data we have presented suggest that the conventional perception of temperate seagrass meadows as systems regulated by abiotic variables, including nutrient dynamics, also needs to be re-evaluated in other regions, and the data highlight the importance of using adequate (i.e. direct) methods to estimate seagrass leaf losses to herbivores in the field.

Acknowledgements. This work was supported by a FI scholarship from the Departament d'Universitats, Recerca I Societat de la Informació (DURSI, Generalitat de Catalunya) and the REN 2002-04020-C02-MAR project funded by the Spanish Ministry of Science and Technology. The authors thank S. Mariani, S. Farina, and S. Escartín for their assistance with field work. We are grateful to the Réserve Naturelle Marine de Cerbère-Banyuls for permission to work within the protected area and their field-work assistance during the first stages of the study. Part of the work was done in the Cap de Creus Marine Protected Area (Jugadora, Port Lligat, and Montjoi sites).

\section{LITERATURE CITED}

Alcoverro T, Mariani S (2004) Patterns of fish and sea urchin grazing on tropical Indo-Pacific seagrass beds. Ecography 27:361-365

Alcoverro T, Duarte CM, Romero J (1995) Annual growth dynamics of Posidonia oceanica: contribution of largescale versus local factors to seasonality. Mar Ecol Prog Ser 120:203-210

Alcoverro T, Manzanera M, Romero J (2001) Annual metabolic carbon balance of the seagrass Posidonia oceanica: the importance of carbohydrate reserves. Mar Ecol Prog Ser 211:105-116

Bjorndal KA (1980) Nutrition and grazing behaviour of the green turtle, Chelonia mydas. Mar Biol 56:147-154

Boudouresque CF, Meinesz A (1982) Découverte de l'herbier de Posidonies. Cah Parc Natl Port-Cros 4:1-79

Boudouresque $\mathrm{CF}_{\text {, Verlaque }} \mathrm{M}$ (2001) Edible sea urchins: biology and ecology. In: Lawrence JM (ed) Developments in aquaculture and fisheries science, Vol 32. Elsevier, Amsterdam, p 177-216

Cebrián J, Duarte CM (1998) Patterns in leaf herbivory on seagrasses. Aquat Bot 60:67-82

Cebrián J, Duarte CM, Marbà N, Enríquez S, Gallegos M, Olesen B (1996) Herbivory on Posidonia oceanica: magnitude and variability in the Spanish Mediterranean. Mar Ecol Prog Ser 130:147-155 
Cyr H, Pace ML (1993) Magnitude and patterns of herbivory in aquatic and terrestrial ecosystems. Nature 361:148-150

Duarte CM (1990) Seagrass nutrient content. Mar Ecol Prog Ser 67:201-207

Esteban JL, Giner IM, Benedito V, Torres J, Capaccioni R, Garcia-Carrascosa AM (1990) Leaf biomass and production of Posidonia oceanica at Spanish eastern coast. Rapp P-V Reun Comm Int Explor Sci Mer Mediterr Monaco 32:8

Fernandez C, Boudouresque CF (2000) Nutrition of the sea urchin Paracentrotus lividus (Echinodermata: Echinoidea) fed different artificial food. Mar Ecol Prog Ser 204:131-141

Francour P (1997) Fish assemblages of Posidonia oceanica beds at Port-Cros (France, NW Mediterranean): assessment of composition and long-term fluctuations by visual census. PSZN I: Mar Ecol 18:157-173

Frantzis A, Grémare A (1993) Ingestion, absortion, and growth rates of Paracentrotus lividus (Echinodermata: Echinoidea) fed different macrophytes. Mar Ecol Prog Ser 95:169-183

Ganter B (2000) Seagrass (Zostera spp.) as food for brent geese (Branta bernicla): an overview. Helgol Mar Res 54: 63-70

Heck KL, Valentine JF (2006) Plant-herbivore interactions in seagrass meadows. J Exp Mar Biol Ecol 330:420-436

Jadot C, Ovidio M, Voss J (2002) Diel activity of Sarpa salpa (Sparidae) by ultrasonic telemetry in a Posidonia oceanica meadow of Corsica (Mediterranean Sea). Aquat Living Resour 15:343-350

Kirsch KD, Valentine JF, Heck KL Jr (2002) Parrotfish grazing on turtlegrass Thalassia testudinum: evidence for the importance of seagrass consumption in food web dynamics of the Florida Keys National Marine Sanctuary. Mar Ecol Prog Ser 227:71-85

Marbà N, Duarte CM, Cebrián J, Gallegos ME, Olesen B, Sand-Jensen K (1996) Growth and population dynamics of Posidonia oceanica on the Spanish Mediterranean coast: elucidating seagrass decline. Mar Ecol Prog Ser 137: 203-213

Moran KL, Bjorndal KA (2005) Simulated green turtle grazing affects structure and productivity of seagrass pastures. Mar Ecol Prog Ser 305:235-247

Nedelec H, Verlaque M (1984) Alimentation de l'oursin Paracentrotus lividus (Lamark) dans un herbier à Posidonia oceanica (L.) Delile en Corse (Méditerranée-France). In: Boudouresque CF, de Grissac J, Olivier J (eds) International Workshop Posidonia oceanica beds, Vol 1. GIS Posidonie, Marseille, p 349-364

Editorial responsibility: Kenneth Heck (Contributing Editor), Dauphin Island, Alabama, USA
Ott J (1980) Growth and production in Posidonia oceanica (L.) Delile. PSZN I: Mar Ecol 1:47-64

Pergent G, Romero J, Pergent-Martini C, Mateo MA, Boudouresque CF (1994) Primary production, stocks and fluxes in the Mediterranean seagrass Posidonia oceanica. Mar Ecol Prog Ser 106:139-146

Pergent G, Rico-Raimondino V, Pergent-Martini C (1997) Fate of primary production in Posidonia oceanica meadows of the Mediterranean. Aquat Bot 59:307-321

Preen A (1995) Impacts of dugong foraging on seagrass habitats: observational and experimental evidence for cultivation grazing. Mar Ecol Prog Ser 124:201-213

Régis MB (1979) Analyse des fluctuations des indices physiologiques chez deux échinoides (Paracentrotus lividus (LMK) et Arbacia lixula L.) du Golfe de Marseille. Tethys 9:167-181

Romero J (1989) Primary production of Posidonia oceanica beds in the Medas Islands (Girona, NE Spain). In: Boudouresque CF, Meinesz A, Fresi E, Gravez V (eds) International workshop on Posidonia oceanica beds, Vol 2. GIS Posidonie, Marseille, p 83-86

Ruiz JM, Pérez M, Romero J (2001) Effects of fish farm loadings on seagrass (Posidonia oceanica) distribution, growth and photosynthesis. Mar Pollut Bull 42:749-760

Tomas F, Turon X, Romero J (2005) Seasonal and small-scale variability of herbivory pressure on the temperate seagrass Posidonia oceanica (L.). Mar Ecol Prog Ser 301: 95-107

Underwood AJ (1997) Experiments in ecology: their logical design and interpretation using analysis of variance. Cambridge University Press, Cambridge

Valentine JF, Heck KL (1991) The role of sea urchin grazing in regulating subtropical seagrass meadows: evidence from field manipulations in the northern Gulf of Mexico. J Exp Mar Biol Ecol 154:215-230

Velimirov B (1984) Grazing of Sarpa salpa (L.) on Posidonia oceanica and utilization of soluble compounds. In: Boudouresque CF, de Grissac J, Olivier J (eds) International Workshop Posidonia oceanica beds, Vol 1. GIS Posidonie, Marseille, p 381-387

Verlaque M (1990) Relations entre Sarpa salpa (Linnaeus, 1758) (Téléostéen, Sparidae), les autres poissons brouteurs et le phytobenthos algal Méditerranéen. Oceanol Acta 13:373-388

Wittmann KJ (1984) Temporal and morphological variations of growth in a natural stand of Posidonia oceanica (L.) Delile. PSZN I: Mar Ecol 5:301-316

Submitted: April 10, 2006; Accepted: November 1, 2006

Proofs received from author(s): May 25, 2007 